

\section{Sumário}

Dossiê

EDITORIAL: INTERNATIONAL LAW AND DE-GLOBALIZATION 16 Ivette Esis, Jaime Tijmes e Juan Enrique Serrano

El régimen jurídico de la Inversión Extranjera Directa: ¿De la limitación a la desGLOBALIZACIÓN?

Ivette Esis Villarroel e Yoselyn Bermúdez Abreu

Desglobalização, Brexit e os novos acordos entre Reino Unido e União Europeia .34 Angela Limongi Alvarenga Alves e Daniel Freire e Almeida

FisCALIDAD Y DESGLOBALIZACIÓN EN UN MUNDO CRECIENTEMENTE UNILATERAL Julio César Muñiz Pérez

Covid, Covax e o Refluxo da Governança Global Salem Hikmat Nasser e Luiza Nogueira Papy

The International Monetary Fund and COVID-19: Old and New Challenges of a Post-World War II INTERNATIONAL INSTITUTION

Virdzhiniya Petrova Georgieva

Artigos Sobre outros temas

RULE OF LAW IN THE INTERNATIONAL ARENA: THE IMPORTANCE OF PRACTICES OF LEGALITY . 112 Angela Jank Calixto

THE WITHDRAWAL OF MEMBER-STATES FROM HUMAN RIGHTS COURTS: IS THE JUDICIALIZATION OF MEGA-POLITICS A NECESSARY CONDITION?. 132

Mikelli Marzzini Lucas Alves Ribeiro e Ernani Rodrigues de Carvalho Neto 
Princípio da precaução e mudança climática: uma análise do Acordo de Paris e das Conferências das Partes.

Jamille Bergamaschine Mata Diz e Carolina Mendonça de Siqueira

A INTERAÇÃo ENTRE OS ESPAÇOS CONSTITUCIONAIS NACIONAIS E INTERNACIONAIS E SEUS IMPACTOS NO SISTEMA DE FONTES DO DIREITO: AS LIÇÕES DA PROTEÇÃO COOPERATIVA DE DIREITOS HUMANOS E O CASO DA INTEGRAÇÃO EUROPEIA ...................................................... 173

Diego Fernandes Guimarães

WTO’s Engagement with National Law: Three Illustrations from India 193 Ravindra Pratap

GESTÃo MIGRATÓRIA E INTEGRAÇÃo REGIONAL: UMA ANÁLISE SOBRE A REGULAMENTAÇÃo NORmativa dos fluxos migratórios irregulares na União Europeia À luz do Novo Pacto Europeu sobre Migração e Asilo.................................................................. 212 João Mauricio Malta Cavalcante Filho e Eugênia Cristina Nilsen Ribeiro Barza

The African Regional Human and Peoples' Rights System: 40 years of progress and CHALLENGES. 232 Juan Bautista Cartes Rodríguez

The USMCA Sunset Clause 258 Jaime Tijmes-Ihl e Yvonne Georgina Tovar Silva

REFLEXÕES SOBRE A UNIVERSALIDADE DO DIREITO INTERNACIONAL DOS DIREITOS HUMANOS A RESPEITO DA PROTEÇÃO ÀS MULHERES 273 Érica Rios de Carvalho

A CRItical legal anAlysis OF GENDER EQUALITY IN INTERNATIONAL TRADE AgREEMENTS...287 Parul Shukla e Sheikh Sultan Aadil Huque

FEMinicídio, FEMicídio E Ódio NA AGENDA: o ASSASSinAto DAS MUlHERES NA AmÉriCA LATINA...... 309 Vinícius Ferreira Baptista

LEGAL IDEOLOGY IN THE CONTEXT OF DEVELOPMENT OF THE LEGAL STATE AND FORMATION OF THE CIVIL SOCIETY IN UKRAINE 
Direito INTERNACIONAL PÚBLICO NO ENTREgUERRAS (1919-39): A INSTITUCIONALIZAÇÃO DOS PROJETOS JURÍDICOS DE PAZ E MANEJO DOS POVOS NÃO SOBERANOS.

Hugo Luís Pena Ferreira

O Caso Gomes Lund (“Guerrilha Do Araguaia”) dez anos depois: Desafios para o cumPRIMENTO INTEGRAL PELO ESTADO BRASILEIRO

João Gabriel Archegas, Felipe Klein Gussoli e Vivian Cristina Lima López Valle

DiÁlogos museológicos: o Regime jurídico brasileiro e o Código de Ética do ConseLHo InTERnacional de Museus.

Paula Gonçalves do Carmo, Emerson Gabardo e Daniel Wunder Hachem 


\title{
Gestão migratória e integração regional: uma análise sobre a regulamentação normativa dos fluxos migratórios irregulares na União Europeia à luz do Novo Pacto Europeu sobre Migração e Asilo*
}

\author{
Migration management and regional \\ integration: an analysis of the normative \\ regulation of irregular migratory flows in \\ the European Union in the light of the New \\ European Pact on Migration and Asylum
}

João Mauricio Malta Cavalcante Filho**

Eugênia Cristina Nilsen Ribeiro Barza***

\section{Resumo}

O artigo propõe uma reflexão crítica acerca das contribuições normativas da integração regional para a gestão das migrações, utilizando, como objeto de análise, a União Europeia. Tem como referência o Novo Pacto Europeu para a Migração e Asilo, e suas perspectivas para o disciplinamento das migrações irregulares. Questiona se o novo pacto representa uma ruptura ou uma continuidade da política migratória restritiva até então vigente no bloco. Diante dessa problemática, analisam-se os fundamentos jurídicos da política de imigração europeia, apontando-se seus impactos para o disciplinamento da imigração irregular. Partindo-se de uma abordagem metodológica qualitativa, utiliza-se do método hipotético-dedutivo para testar a hipótese de que as novas soluções da UE não representam ruptura jurídica significativa com a política migratória até então reconhecida no arranjo europeu. A partir da revisão bibliográfica e da análise das fontes do direito da UE, com base na Teoria da Integração Econômica aplicada à mobilidade humana, o artigo resulta da verificação de que o novo pacto reitera mecanismos de regresso e reforço de fronteiras como alternativas à irregularidade migratória. As conclusões apontam que a iniciativa analisada não inova, juridicamente, na essência defensiva da política migratória europeia, o que confirma a hipótese inicialmente aventada.

Palavras-chave: Direito internacional; Integração regional; Gestão migratória; Migração irregular; União Europeia.

\footnotetext{
*** Doutora e Mestre em Direito pelo Programa de Pós-Graduação em Direito da Universidade Federal de Pernambuco (PPGD-UFPE). Professora Associada da Faculdade de Direito do Recife - Centro de Ciências Jurídicas (CCJ), da UFPE. Professora dos cursos de Mestrado e Doutorado do Programa de Pós-Graduação em Direito da UFPE. Líder do Grupo de Pesquisa "Integração Regional, Globalização e Direito. Email: eugenia.barza@ufpe.br
}

\section{Abstract}

The article proposes a critical reflection on the normative contributions of regional integration to the management of migration, using the European 
Union as an object of analysis. With reference to the New European Pact for Migration and Asylum and its prospects for irregular migration, the research questions whether the new pact represents a rupture or a continuation of the current restrictive migration policy. The objective is to analyze the foundations of European immigration policy, seeking to point out its impacts on the disciplining of irregular immigration. Starting from a qualitative methodological approach, the hypotheticaldeductive method is used to test the hypothesis that the new EU solutions do not represent a significant break with the migration policy hitherto recognized. From the bibliographical review and the analysis of the sources of EU law, under the framework of a theory of economic integration applied to human mobility, the article results in the verification that the new pact reiterates mechanisms of return and reinforcement of borders as alternatives to migratory irregularity. The conclusions point out that the analyzed initiative does not legally innovate in the defensive essence of the European migration policy, which confirms the hypothesis initially raised.

Keywords: International law; Regional integration; Migration management; Irregular migration; European Union.

\section{Introdução}

Os projetos de integração regional, a partir das etapas mais avançadas, tendem a formar centros normativos de disciplinamento das migrações, que trazem a necessidade de equilibrar as competências nacionais e as competências comunitárias na regulamentação da mobilidade humana. Especificamente no contexto da União Europeia (UE), a busca por uma política comum de imigração, assentada no Princípio da Solidariedade e da Partilha Equitativa de Responsabilidades entre os Membros, tem exigido esforços adicionais do arranjo europeu no sentido de fornecer respostas efetivas aos desafios impostos pela chegada maciça de pessoas ao bloco, sobretudo em face dos fluxos migratórios considerados irregulares à luz do direito da UE.

Não obstante a evolução normativa do bloco europeu em matéria de disciplinamento das migrações, a chamada crise migratória de 2015-2016 expôs sérias lacunas no sistema de disciplinamento da mobilidade humana, demandando respostas das instituições supranacionais. Dentre as soluções encontradas pelo bloco para o disciplinamento da imigração no espaço comum, destaca-se a recente proposta de um Novo Pacto Europeu para a Migração e Asilo, adotado pela Comissão Europeia em setembro de 2020. O Pacto representa uma tentativa de reunir as soluções do bloco para a imigração extracomunitária, com a promessa de equilibrar as competências supranacionais e as competências dos Estados-membros para a efetiva gestão do fenômeno migratório, muito embora não solucione, plenamente, as questões recorrentes na política de imigração europeia para os fluxos irregulares.

Partindo desse contexto de análise, o artigo propõe uma reflexão crítica acerca das contribuições normativas da integração regional para a gestão migratória, utilizando como objeto de estudo a experiência da UE. Centrando a análise no Novo Pacto Europeu para a Migração e nas suas eventuais inovações para o disciplinamento das migrações irregulares, a pesquisa questiona se o novo Pacto representa uma ruptura da política migratória vigente na UE ou, se ao contrário, indica uma continuidade da abordagem defensiva até então praticada na gestão das migrações não autorizadas.

Diante do problema apresentado, o artigo tem como objetivo geral analisar a regulamentação normativa da imigração no âmbito do processo europeu. Especificamente, abordam-se as contribuições jurídicas da integração regional para a gestão migratória na UE e analisam-se as normativas que compõem a política de imigração do bloco, destacando as perspectivas do novo Pacto Europeu para o disciplinamento da imigração irregular.

Para alcançar os objetivos propostos, parte-se de uma abordagem metodológica qualitativa, utilizando-se do método hipotético-dedutivo, para testar a hipótese de que as novas soluções normativas da UE não representam uma ruptura jurídica significativa com a política migratória reconhecida, na medida em que o novo Pacto continua reforçando mecanismos de regresso, readmissão e reforço das fronteiras como soluções aos deslocamentos irregulares. A partir da revisão bibliográfica e da análise das fontes do direito europeu, a pesquisa promove uma revisão crítica da Teoria Clássica da Integração Econômica aplicada à mobilidade humana em espaços regionais, a fim de questionar as contribuições da UE para a gestão das migrações. 
Seguindo o panorama traçado pelo artigo, na seção inaugural, abordam-se os fundamentos jurídicos da integração regional e suas contribuições para a regulamentação das migrações. Na segunda seção, analisa-se, especificamente, a política de imigração da UE, com foco no disciplinamento das migrações irregulares. $\mathrm{Na}$ terceira seção, aborda-se o Novo Pacto Europeu para as Migrações, destacando suas propostas para a gestão dos fluxos migratórios não autorizados. Ao final, as conclusões indicam que o Pacto não inova juridicamente na política de imigração restritiva até então aplicada na UE, já que reitera mecanismos de regresso e reforço de fronteiras como alternativas à irregularidade migratória, o que confirma a hipótese aventada.

\section{Gestão migratória e integração regional}

O disciplinamento da migração internacional, entendida como o movimento de pessoas que atravessam uma fronteira internacional para se estabelecerem em um país do qual não são nacionais ${ }^{1}$, tornou-se um dos principais temas do presente século. $\mathrm{O}$ incremento dos processos de mobilidade humana constitui uma dinâmica chave em relação ao processo de globalização, em que não apenas bens, capitais e informações circulam amplamente, mas, também, pessoas ${ }^{2}$, o que coloca desafios de regulamentação que influenciam tanto as políticas migratórias nacionais quanto as relações multilaterais e regionais estabelecidas entre os Estados.

Segundo Wihtol de Wenden ${ }^{3}$, no início do século XXI, as migrações internacionais alcançaram uma dimensão sem precedentes. Dentre os vetores que influenciam os processos migratórios atuais, destacam-se fatores relacionados a eventos agudos, como instabilidades severas, crises econômicas e ambientais ou conflitos armados que produzem deslocamentos forçados,

\footnotetext{
${ }^{1}$ INTERNATIONAL ORGANIZATION FOR MIGRATION. Glossary on migration. Genebra: IOM, 2019. p. 113.

2 VILLAMAR, Maria. Regionalismos e migrações internacionais na América do Sul: contexto e perspectivas futuras sobre as experiências na Comunidade Andina, no Mercosul e na Unasul. Espaço Aberto, Rio de Janeiro, v. 8, n. 2, p. 131-148, 2018. Disponível em: https://revistas.ufrj.br/index.php/EspacoAberto/article/view/20197 Acesso em: 02 jun. 2021.

3 WENDEN, Catherine Wihtol de. As novas migrações. Dossiê sobre Migrações e Direitos Humanos. Revista Sur, São Paulo, v. 13, n. 23, p. 17-28, 2016.
}

bem como tendências de longo prazo, associadas a mudanças demográficas, disparidades de desenvolvimento econômico entre as nações, avanços das tecnologias de comunicação e acesso ao transporte internacional.

Apesar da dificuldade em comparar os fluxos atuais com os fluxos passados, diante das diferenças de contexto e do caráter transnacional das migrações contemporâneas ${ }^{4}$, os processos migratórios hodiernos têm impactado, significativamente, as comunidades de origem e de destino, gerando repercussões jurídicas na tentativa de regulamentar a matéria no âmbito interno, internacional e regional.

Sob o aporte jurídico, é tarefa difícil apontar uma regulamentação uniforme e globalmente aceita para um fenômeno tão complexo e multiforme quanto à ideia de migração internacional. A fragmentariedade do sistema global e as particularidades das legislações migratórias nacionais e regionais trazem definições que variam conforme os critérios de entrada, residência, permanência e circulação, adotados nos sistemas normativos, diante da pluralidade de direitos sociais, econômicos e políticos que podem ser reconhecidos ou negados aos estrangeiros. Como resultado, observa-se um complexo emaranhado normativo que se revela em múltiplos níveis de normatividade, nos termos das leis nacionais, dos acordos resultantes dos blocos regionais e das organizações internacionais que regulamentam o tema.

Em decorrência da multiplicação das esferas normativas que tratam do movimento internacional de pessoas, a gestão migratória, entendida como o conjunto de atividades voltadas ao disciplinamento de todos os aspectos da migração por meio de uma abordagem planejada de implementação e operacionalização do quadro político, administrativo e legislativo ${ }^{5}$, passa a conformar um regime jurídico específico para a regulamentação da matéria. Esse regime jurídico é baseado no acesso legítimo a direitos e a territórios ${ }^{6}$, mas, também,

\footnotetext{
4 SOBRINHO, Liton; SIRIANNI, Guido; PIFFER, Carla. Migrações transnacionais e multiculturalismo: um desafio para a União Europeia. Novos Estudos Jurídicos, v. 19, n. 4, p. 1.159-1.184, 2014. Disponível em: https://siaiap32.univali.br/seer/index.php/nej/article/view/6702/0 Acesso em: 02 jun. 2021.

5 INTERNATIONAL ORGANIZATION FOR MIGRATION. Glossary on migration. Genebra: IOM, 2019. p. 137.

${ }^{6}$ OELGEMOLLER, Christina; ALLINSON, Kathryn. The Responsible Migrant, Reading the Global Compact on Migration. Law and Critique, v. 31, p. 183-207, 2020. Disponível em: https://link. springer.com/article/10.1007/s10978-020-09265-9 Acesso em: 28 maio 2021.
} 
envolve os limites impostos ao processo migratório, em face dos deslocamentos que ocorrem à margem das vias legalmente reconhecidas.

Sobre o regime jurídico aplicável às migrações, esclarece-se que a migração internacional destaca interdependências na ordem internacional que adquirem ressonâncias específicas nos diferentes níveis de disciplinamento existentes, sobretudo no nível regional ${ }^{7}$, principal foco desta seção. A regulamentação do tema enseja o incremento das interações entre os países, o que pode culminar em modalidades de cooperação mais estreita entre os Estados, até chegar, efetivamente, à criação de espaços regionais de mobilidade, quando países geograficamente próximos se vêem compartilhando desafios semelhantes em relação à mobilidade e à migração.

No âmbito regional, as normativas que disciplinam as migrações estão associadas, fundamentalmente, aos chamados blocos de integração regional. Tradicionalmente, a integração regional é concebida como um processo de associação interestatal ${ }^{8}$ em que os países decidem oferecer, reciprocamente, determinadas vantagens, principalmente no âmbito econômico, objetivando alcançar benefícios mútuos e fortalecer a defesa de interesses comuns no contexto internacional ${ }^{9}$. Assentados em sistemas normativos, tais processos estão voltados à redução ou supressão de barreiras à interação transfronteiriça em dada região, sejam essas barreiras físicas, econômicas ou jurídicas.

De acordo com a Teoria Clássica da Integração Econômica $^{10}$, o aspecto comercial está na base desses processos integrativos, que se destinam à redução das discriminações entre as economias dos países participantes. No entanto, à medida que o projeto regional avança, o bloco passa a irradiar efeitos para além de aspectos meramente mercantis. Fatores relativos às di-

GEDDES, Andrew et al. The dynamics of regional migration governance. Northampton: Edgar Elgar Publishing, 2019. p. 7.

8 DIZ, Jamile; JAEGER JÚNIOR, Augusto. Por uma teoria jurídica da integração regional: a interrelação direito interno, direito internacional público e direito da integração. Revista de Direito Internacional, Brasília, v. 12, n. 2, p. 138-158, 2015. Disponível em: www.publicacoesacademicas.uniceub.br/rdi/article/view/3710/pdf\# Acesso em: 02 jun. 2021.

9 PORTELA, Paulo. Direito internacional público e privado: incluindo noções de direitos humanos e de direito comunitário. Salvador: Juspodium, 2016. p. 1020.

10 BALASSA, Bela. Teoria da integração econômica. Lisboa: Livraria Clássica, 1961 mensões sociais da integração regional passam a conformar a estrutura dos blocos, que demandam a adoção de normativas capazes de facilitar a integração em domínios classicamente disciplinados no direito interno, a exemplo da imigração, no intuito de equilibrar competências dos Estados-membros e das instâncias regionais.

Para alcançar os objetivos traçados, o arranjo integrativo conta com uma estrutura normativa especificamente destinada ao disciplinamento das relações jurídicas estabelecidas no espaço comum, buscando trazer maior previsibilidade para a ação dos países em um cenário de crescente interdependência e complexidade normativa. Os blocos regionais tendem a realocar, reduzir ou eliminar as barreiras que obstaculizam as interações no espaço integrado, gerando maior circulação de fatores produtivos que podem levar à liberdade de circulação de bens, serviços, capitais e pessoas, a fim de formar um arranjo efetivamente integrado.

Sobretudo em etapas mais avançadas, os blocos podem formar acordos específicos para facilitar, internamente, a livre circulação de pessoas, enquanto buscam adotar uma política migratória regional para os fluxos migratórios externos. A crescente mobilidade de pessoas em áreas de integração, por sua vez, impulsiona a produção de normas específicas sobre as condições de entrada, circulação, residência e trabalho no espaço comum.

Em matéria de migração, os sistemas jurídicos resultantes dos blocos regionais, tanto em modelos mais incisivos, pautados na supranacionalidade normativa, quanto em modelos intergovernamentais, pautados no entendimento recíproco entre os $\operatorname{membros}^{11}$, manifestam regras de produção que demandam o cumprimento ao tratarem dos direitos de mobilidade tutelados no espaço integrado. As iniciativas regionais podem abarcar desde a adoção de regras voltadas à isenção de vistos para os deslocamentos intrarregionais, a partir da supressão de controles fronteiriços internos, até a implementação de uma política regional de atração de imigrantes qualificados, passando pela adoção de regras comuns para gestão de fronteiras externas e para

\footnotetext{
11 DIZ, Jamile; JAEGER JÚNIOR, Augusto. Por uma teoria jurídica da integração regional: a interrelação direito interno, direito internacional público e direito da integração. Revista de Direito Internacional, Brasília, v. 12, n. 2, p. 138-158, 2015. Disponível em: www. publicacoesacademicas.uniceub.br/rdi/article/view/3710/pdf\# Acesso em: 02 jun. 2021.
} 
procedimentos de retorno de imigrantes em situação de irregularidade.

A partir de tais normativas, os arranjos integrativos contribuem para o disciplinamento das migrações internacionais, já que constituem centros disciplinadores da mobilidade humana, apresentando normativas próprias, distintas do direito internacional e também do direito interno, visando à regulamentação tanto dos deslocamentos intrarregionais, representados pelos esquemas internos de livre circulação de pessoas, quanto inter-regionais, em relação à harmonização do tratamento dos fluxos migratórios externos. As normas resultantes dos blocos regionais oferecem alternativas relevantes de regulamentação migratória, na medida em que não se apresentam nem tão restritivas quanto o âmbito de aplicação do direito interno, tampouco abrangentes e de difícil supervisão normativa, como as iniciativas globais.

Apesar das contribuições jurídicas identificadas, cumpre esclarecer que a gestão migratória ainda encontra entraves de regulamentação nas experiências regionais. Como esclarece Lavenex ${ }^{12}$, a migração ainda é encarada como o último reduto de soberania do Estado-nação, em que os países relutam em transferir competências às instâncias regionais. Ademais, o processo integrativo enseja compromissos recíprocos em favor dos Estados-membros, pressionando as legislações internas a liberalizarem os deslocamentos intrarregionais, em favor dos cidadãos dos países do bloco, enquanto se busca um controle reforçado dos fluxos migratórios extrarregionais, com base na solidariedade e na partilha equitativa de responsabilidades ${ }^{13}$, como ocorre na UE, o que tem gerado uma dualidade de disciplinamento pautada na distinção de tratamento concedido aos imigrantes.

A referida dualidade de tratamento jurídico se revela na concessão de privilégios de circulação e residência aos cidadãos do bloco, enquanto esses mesmos direitos tendem a ser enrijecidos para os nacionais de países terceiros, os quais enfrentam entraves adicionais caso

${ }_{12}$ LAVENEX, Sandra. Migration. In: BORZEL, Tanja; DRAUDE, Anke; RISSE, Thomas. (eds.). The Oxford Handbook of Governance and Limited Statehood. Oxford: Oxford University Press, 2018. p. 520-543. p. 520 .

${ }^{13}$ ILHA, Jônatas; REIS, Jorge. O papel do princípio jurídico da solidariedade no direito da União Europeia em casos de crise migratórias: amor em tempo de muros. Caderno de Relações Internacionais, v. 10, n. 19, p. 71-89, 2019. Disponível em: https://faculdadedamas. edu.br/revistafd/index.php/relacoesinternacionais/article/ view/1174/906 Acesso em: 30 abr. 2021. se desloquem em situação de irregularidade. Em um processo de integração regional, tende-se, portanto, a separar a ideia de livre circulação de pessoas e de imigração, já que a livre circulação enseja a permeabilidade dos limites fronteiriços, ao passo que a noção de gestão migratória reafirma o poder de controle dos Estados no bojo da soberania territorial.

Por conseguinte, os Estados-membros continuam relevantes nas competências relativas à gestão migratória, sobretudo em um contexto de desconfiança do regionalismo, que traz efeitos desintegradores já sentidos em alguns blocos, como no caso da saída do Reino Unido da $\mathrm{UE}^{14}$. As funções disciplinadoras dos blocos regionais são, ainda, contestadas por correntes que se opõem à globalização, à imigração e à política de consenso, a partir da retomada do nacionalismo e da crença de que o Estado-nação seria o ente mais adequado para gerir as migrações, principalmente em situações de crise, sejam elas de caráter migratório ou de saúde pública, quando se incrementam as restrições, como ocorreu, por exemplo, na pandemia de Covid- $19^{15}$.

A integração econômica pressupõe o desejo de participar de um projeto comum que, embora traga benefícios, atribui aos Estados uma série de obrigações com metas de solidariedade e cooperação, que pressupõem ajustes econômicos, jurídicos e políticos. No entanto, em contextos de crise, tais metas tendem a ser entendidas como remédios amargos, por exemplo, quando a recessão ou as ondas migratórias rompem as fronteiras regionais ${ }^{16}$. Nesses contextos, nem sempre as barreiras da integração são eliminadas completamente. Ao contrário, podem ser deslocadas ou reforçadas.

Exemplo paradigmático do reposicionamento de barreiras às migrações ocorre no âmbito da UE, o que justifica a seleção dessa experiência regional como ob-

${ }^{14}$ DEL'OLMO, Florisbal; ROTTA, Guilherme. "BREXIT": da integração regional à política de controle de mobilidade humana. Revista Brasileira de Direito Internacional, Curitiba, v. 2, n. 2, p. 100-117, 2016. Disponível em: www.indexlaw.org/index.php/direitointernacional/article/view/1651/2136 Acesso em: 28 maio 2021.

15 VIEIRA, Luciane; COSTA, Vitória. A resposta comum da UE frente à pandemia de COVID-19 e os compromissos com a proteção internacional dos direitos humanos de imigrantes e refugiados. In: BAENINGER, Rosana; VEDOVATO, Luís; NANDY Shailen (coord.). Migrações internacionais e a pandemia de Covid-19. Campinas: Nepo/Unicamp, 2020. p. 232-254. p. 230.

16 GLITZ, Frederico. Brexit, Direito contratual europeu e Mercosul: lições para a integração. Novos Estudos Jurídicos, v. 23, n. 2, p. 549577, 2018. Disponível em: https://siaiap32.univali.br/seer/index. php/nej/article/viewFile/13409/7618 Acesso em: 02 jun. 2021. 
jeto de estudo do presente artigo. No bloco europeu, a desmobilização das fronteiras internas conduziu ao deslocamento de controles para as fronteiras externas, reforçando os limites no intuito de garantir uma gestão seletiva e coordenada dos fluxos exteriores, particularmente em relação à imigração irregular, o que gerou um esforço generalizado de contenção desses fluxos, com base na securitização de fronteiras e nas devoluções de migrantes em situação de irregularidade, prerrogativas reforçadas nos contextos de crise migratória ${ }^{17}$ e nas recentes iniciativas comunitárias, como o novo Pacto das Migrações e Asilo ${ }^{18}$, que será detalhado nas seções seguintes.

As repercussões jurídicas desse modelo de regulamentação são significativas e podem culminar na criação de novos muros, físicos e jurídicos, para as migrações, sobretudo em relação aos fluxos não autorizados. Em última instância, a integração regional contribui para a gestão migratória porque flexibiliza parcialmente os limites territoriais, mas sem deixar de conferir margem de atuação aos Estados-membros, que podem reforçar tais limites em relação aos fluxos externos, a partir do acirramento de controles fronteiriços e migratórios, como ilustra o caso da UE, nos termos que se passa a aprofundar.

\section{A política de imigração da UE:} fundamentos jurídicos e propostas para o disciplinamento das migrações irregulares

Dentre os processos de integração existentes, a UE se mostra como um arranjo ilustrativo do regime dual de disciplinamento da mobilidade humana em espaços regionais. O modelo europeu consolidou, internamente, um espaço comum de livre mobilidade, favorecendo os deslocamentos dos cidadãos do bloco, enquanto buscou adotar uma política comum de imigração, baseada

\footnotetext{
${ }^{17}$ SCHIMMELFENNIG, Frank. Rebordering Europe: external boundaries and integration in the European Union. Journal of European Public Policy, v. 28, n. 3, p. 311-330, 2021. Disponível em: www. tandfonline.com/doi/full/10.1080/13501763.2021.1881589 Acesso em: 28 maio 2021.

18 COMISSÃO EUROPEIA. Comunicação da Comissão sobre um novo Pacto em matéria de Migração e Asilo. 2020. Disponível em: https:/ / eur-lex. europa.eu/legal-content/PT/TXT/?uri=CELEX:52020DC0609 Acesso em: 30 abr. 2021.
}

na solidariedade e na partilha equitativa de responsabilidades, a fim de estabelecer a abordagem comunitária no tratamento das migrações externas. Para garantir a efetiva gestão migratória nesse espaço comum, o bloco europeu tem apostado em estratégias jurídicas voltadas à vigilância fronteiriça e à contenção da irregularidade migratória, razão pela qual a presente seção passa a analisar a evolução da UE em matéria de imigração extracomunitária, focando nas propostas de disciplinamento das migrações irregulares.

Inicialmente, é importante pontuar que, em arranjos regionais pautados pela supranacionalidade normativa, como ocorre na UE, o processo de integração envolve a criação de instituições supranacionais em que a autoridade política é delegada para tomar decisões coletivamente vinculativas ${ }^{19}$. A amplitude de temas tratados no contexto da integração europeia, por sua vez, coloca desafios adicionais no sentido de equilibrar competências nacionais e comunitárias em questões outrora vinculadas estritamente ao direito interno, a exemplo do que acontece na regulamentação da mobilidade humana.

Sob o aporte jurídico, o modelo de integração regional adotado na UE resultou em um sistema normativo capaz de formular e aplicar regras comunitárias que disciplinam temas sensíveis aos Estados, como migração, fronteiras e livre circulação de pessoas. A partir dos princípios do direito da UE, firmados na primazia, aplicabilidade imediata e efeito direto das normas comunitárias, consolidou-se um arranjo regional em que a forma jurídica adotada garante a homogeneidade necessária, diante das particularidades nacionais ${ }^{20}$. O sistema supranacional da UE, portanto, forma o plano de fundo a partir do qual se analisa o fundamento jurídico da sua política de imigração.

Em relação ao disciplinamento das migrações, a referida estrutura comunitária consolidou um sistema específico aplicado à mobilidade humana, com vistas a assegurar a livre circulação de pessoas no espaço comum, ao mesmo tempo em que se busca harmonizar as mi19 BORZEL, Tanja. Theorizing regionalism: cooperation, integra-
tion, and governance. In: BORZEL, Tanja; RISSE, Thomas (eds.).
The Oxford Handbook on Comparative Regionalism. Oxford: Oxford Uni-
versity Press, 2016. p. 53 .
20 OSÓRIO, Luiz. O direito da União Europeia e a deterioração
democrática e social. Revista Eletrônica do Curso de Direito da UFSM,
Santa Maria, v. 13, n. 1, p. 295-318, 2018. Disponível em: https://
periodicos.ufsm.br/revistadireito/article/view/29158/pdf Acesso
em: 30 maio 2021. 
grações extracomunitárias. Por essa razão, a análise da política de imigração da UE pressupõe a menção prévia à livre circulação de pessoas, que se constitui como uma prerrogativa fundamental para compreensão do regime migratório do bloco. Ambas integram duas faces de um mesmo sistema de disciplinamento da mobilidade humana que reproduz um modelo de regulamentação dicotômico, já que as normativas comunitárias demandam uma abertura de disciplinamento para os fluxos intrarregionais, em que os europeus não são tratados como imigrantes, mas como cidadãos comunitários, ao mesmo tempo em que se observa um fechamento seletivo para os fluxos extrarregionais, em que os movimentos de nacionais de países terceiros que pretendam se estabelecer na UE são tratados com base na política de imigração europeia.

Em relação às disposições europeias para a liberdade de circulação de pessoas, entendida como a prerrogativa de movimentar-se, para exercer atividades econômicas ou não, bem como disponibilizar-se no espaço regional sem que sejam impostas restrições injustificadas, destaca-se que essa liberdade constituiu prerrogativa fundamental para o bloco. No caso europeu, o disciplinamento da livre circulação aponta, fundamentalmente, para o chamado Espaço Schengen, composto atualmente por 26 países, que incluem 22 Estados-membros da UE, acrescido de Estados associados, como Noruega, Islândia, Suíça e Listenstaine ${ }^{21}$.

O acervo Schengen consiste em um modelo de livre circulação adotado originariamente fora do sistema comunitário, buscando a abolição dos controles nas fronteiras comuns, a partir do acordo de Schengen de 1985 e de sua convenção de aplicação de 1990. Posteriormente, foi incorporado ao quadro legislativo comunitário ${ }^{22}$. O referido espaço representa uma das principais conquistas do sistema europeu, na medida em que abarca normativas voltadas à abolição dos controles nas fronteiras internas, a harmonização e o reforço dos controles nas fronteiras externas, a adoção de uma política comum de vistos e o incentivo à cooperação policial e judiciária.

\footnotetext{
21 PARLAMENTO EUROPEU. Livre circulação de pessoas. 2021. Disponível em: https://www.europarl.europa.eu/factsheets/pt/ sheet/147/livre-circulacao-de-pessoas Acesso em: 30 maio 2021.

22 COSTA, Vitória; VIEIRA, Luciane. Nacionalismo, xenofobia e União Europeia: barreiras à livre circulação de pessoas e ameaças ao futuro do bloco europeu. Revista da Faculdade de Direito UFPR, Curitiba, v. 64, n. 3, p. 133-160, 2019. Disponível em: https://revistas. ufpr.br/direito/article/view/65536 Acesso em: 02 jun. 2021.
}

Seguindo a evolução normativa do bloco, com a assinatura do Tratado de Maastricht, que efetivamente criou a UE, instituiu-se uma cidadania comunitária ou cidadania da UE, como aponta Moura ${ }^{23}$. Tal instituto não substitui a cidadania nacional, mas significa o reconhecimento de prerrogativas no nível regional, beneficiando os nacionais dos Estados-membros da UE. Dentre os direitos reconhecidos, destaca-se a liberdade de circulação e residência no espaço comum, que se confirma como uma liberdade dissociada de condições laborais, no sentido de reconhecer um direito autônomo à livre circulação para os europeus. Como resultado, os deslocamentos dos europeus no bloco passaram a se relacionar mais como uma prerrogativa de cidadania regional do que com um movimento migratório propriamente dito.

A respeito desse ponto, destaca-se, como explicam Vieira e $\operatorname{Costa}^{24}$, que a previsão da livre circulação de pessoas na Europa abarca duas dimensões. De um lado, a liberdade de circulação de pessoas prevista nos tratados do bloco, que abrange todos os nacionais dos Estados-membros. De outra parte, as disposições referentes à supressão de controle nas fronteiras internas entre os países que fazem parte do Espaço Schengen, sejam eles membros ou não da UE.

Acerca do reconhecimento da livre circulação de pessoas no espaço comum, cumpre destacar, ainda, a contribuição das instâncias comunitárias para o tema, em especial, a jurisprudência do Tribunal de Justiça da União Europeia (TJUE). Como afirma Acosta ${ }^{25}$, a atuação do TJUE, na função de intérprete da legislação da UE, facilitou o acesso efetivo aos direitos dos cidadãos comunitários que exercem suas prerrogativas de livre circulação na Europa, muito embora tais prerrogativas

${ }^{23}$ MOURA, Aline. Caratteri ed effetti della cittadinanza tra diritto internazionale e fenomeni di integrazione regionale: Unione Europea e Mercosul. Tese (Doutorado em Direito) - UNIMI, Milão. 2014. Disponível em: https://air.unimi.it/retrieve/handle/2434/231101/300764/ phd_unimi_R09209pdf. Acesso em: 14 abr. 2021.

${ }^{24}$ VIEIRA, Luciane; COSTA, Vitória. A resposta comum da UE frente à pandemia de COVID-19 e os compromissos com a proteção internacional dos direitos humanos de imigrantes e refugiados. In: BAENINGER, Rosana; VEDOVATO, Luís; NANDY Shailen (coord.). Migrações internacionais e a pandemia de Covid-19. Campinas: Nepo/Unicamp, 2020. p. 232-254. p. 235.

25 ACOSTA, Diego. Global migration law and regional free movement: compliance and adjudication. American Journal of International Law, v. 111, p. 159-164, 2017. Disponível em: https://bit.ly/3d81YJe Acesso em: 30 jun. 2021. 
não tenham sido plenamente estendidas aos migrantes extracomunitários.

No âmbito da jurisprudência europeia, o TJUE, desde o caso Grzelcayy $k^{26}$, já reconhecia a ligação existente entre a situação pessoal e o exercício de um direito de livre circulação no espaço comum. Em outras palavras, o Tribunal fixou um dos pilares da jurisprudência sobre a cidadania europeia, ao estabelecer que o estatuto de cidadão da União tende a ser o estatuto fundamental dos nacionais dos Estados-membros que permite a obtenção do mesmo tratamento jurídico aos que, entre estes, se encontrem na mesma situação, independentemente da sua nacionalidade e sem prejuízo das exceções expressamente previstas. O TJUE reconheceu também o efeito direto do direito de permanência dos cidadãos da UE, como no caso Baumbast ${ }^{27}$, tutelando os cidadãos europeus economicamente inativos que vivem legalmente em outro Estado-membro. Por essa razão, Lanceiro ${ }^{28}$ afirma que o Tribunal foi relevante para a construção de uma cidadania europeia desligada de um necessário vínculo laboral ou econômico.

O disciplinamento atual do tema encontra respaldo no Tratado de Lisboa, em vigor desde 2009, que confirmou o direito de livre circulação e residência, também incluído nas disposições gerais relativas ao Espaço de Liberdade, Segurança e Justiça ${ }^{29}$, objetivando assegurar a ausência de controles de pessoas nas fronteiras internas e desenvolver uma política comum em matéria de asilo, de imigração e de controle das fronteiras externas. A partir da evolução normativa apresentada, observa-se que a UE reproduz um modelo de dualidade que favorece determinados fluxos de pessoas, a partir da concessão de privilégios de circulação e residência, principalmente aos cidadãos do bloco e aos migrantes regulares, enquanto busca enrijecer os controles em relação

\footnotetext{
26 UNIÃO EUROPEIA. Tribunal de Justiça da União Europeia. Caso Grzelcaylk (C-184/99). Acórdão de 20 setembro 2001. Disponível em: https://bit.ly/3dBmPGP Acesso em: 30 jun. 2021.

${ }^{27}$ UNIÃO EUROPEIA. Tribunal de Justiça da União Europeia. Caso Baumbast (C-413-99). Acórdão de 12 setembro 2002. Disponível em: https://eur-lex.europa.eu/legal-content/PT/TXT/ PDF/?uri=CELEX:61999CJ0413 Acesso em: 02 jul. 2021.

28 LANCEIRO, Rui. Dano e Alimanovic: a recente evolução da jurisprudência do TJUE sobre a cidadania da UE e acesso transfronteiriço aos benefícios sociais. UNIO - EU Law Journal, v. 3, n. 1, p. 65-80, 2017. Disponível em: https://revistas.uminho.pt/index.php/ unio/article/download/320/327/636 Acesso em: 02 jul. 2021.

29 PARLAMENTO EUROPEU. Livre circulação de pessoas. 2021 Disponível em: https://www.europarl.europa.eu/factsheets/pt/ sheet/147/livre-circulacao-de-pessoas Acesso em: 30 maio 2021.
}

a outros tipos de deslocamentos tidos por indesejados, principalmente em relação à imigração extracomunitária irregular.

Como esclarecem Silva e Amaral ${ }^{30}$, estabeleceu-se uma fortaleza burocrática, mediante a exigência de rígidos requisitos para concessão de visto e circulação aos imigrantes de terceiros Estados, reforçando fronteiras externas e fomentando mecanismos de vigilância e monitoramento, a fim de selecionar quem estava apto a circular e permanecer no espaço comum. Em consequência, as normativas analisadas aprofundam a abertura das fronteiras internas para a livre circulação, ao mesmo tempo em que fecham as fronteiras externas, o que fomenta um sistema dicotômico, comparativamente mais flexível para europeus, mas que é rígido e oneroso para o resto do mundo.

Como corolário dessa abertura parcial aos fluxos intrarregionais, passou-se a demandar a gestão integrada das fronteiras externas e dos fluxos migratórios extracomunitários, como esclarece Porto ${ }^{31}$, levando à tentativa de construção progressiva de uma política de imigração europeia. O contexto de análise dessa política, porém, tem se fundamentado na crescente exclusão da pessoa migrante com base no status jurídico-político de alguns, como resultado da convulsão no Oriente Médio e do aumento da securitização e externalização das frontei$\operatorname{ras}^{32}$, a partir do cenário de crise observado na última década.

No mesmo sentido, Costa e Vieira ${ }^{33}$ ressaltam a preocupação de uma política de imigração europeia para gerir os vultosos fluxos de pessoas que chegam ao continente de terceiros Estados, muitas das quais em

30 SILVA, Wanise; AMARAL, Nemo. A imigração na Europa: a ação política da União Europeia para as migrações extracomunitárias. Sequência, Florianópolis, n. 66, p. 235-259, 2013. Disponível em: https://www.scielo.br/pdf/seq/n66/10.pdf Acesso em: 29 abr. 2021.

31 PORTO, Manuel. O novo pacto sobre migração e asilo: as responsabilidades da Europa. Polis, n. 2, v. 2, p. 97-106, 2020. Disponível em: http://revistas.lis.ulusiada.pt/index.php/polis/article/ view/2875/pdf Acesso em: 02 jun. 2021.

32 OELGEMOLLER, Christina; ALLINSON, Kathryn. The Responsible Migrant, Reading the Global Compact on Migration. Law and Critique, v. 31, p. 183-207, 2020. Disponível em: https://link. springer.com/article/10.1007/s10978-020-09265-9 Acesso em: 28 maio 2021

33 COSTA, Vitória; VIEIRA, Luciane. Nacionalismo, xenofobia e União Europeia: barreiras à livre circulação de pessoas e ameaças ao futuro do bloco europeu. Revista da Faculdade de Direito UFPR, Curitiba, v. 64, n. 3, p. 133-160, 2019. Disponível em: https://revistas. ufpr.br/direito/article/view/65536 Acesso em: 02 jun. 2021. 
situação de irregularidade, gerando um aumento da xenofobia, do nacionalismo e do euroceticismo. A análise dos fundamentos jurídicos da política comum de imigração precisa abarcar tais fatores que influenciam o equilíbrio entre as competências nacionais e comunitárias, e a busca pela adequação de disposições unilaterais às amarras do próprio sistema europeu.

No que se refere à evolução normativa da referida política de imigração, observa-se uma passagem progressiva de uma abordagem inicial pautada na cooperação intergovernamental até a busca por uma abordagem comunitária do tema ${ }^{34}$. Enquanto a política de imigração estava centrada no pilar de cooperação intergovernamental, o tratamento supranacional da matéria encontrava óbices de regulamentação porque os Estados optavam por manter a questão migratória, em larga medida, subordinada aos interesses nacionais ${ }^{35}$. Com a progressiva comunitarização do tema, a UE foi autorizada a adotar instrumentos comunitários vinculativos no domínio estudado.

Finalmente, com a entrada em vigor do Tratado de Lisboa, em 2009, sedimentaram-se os fundamentos jurídicos da atual política migratória no direito europeu, evocando uma abordagem mais supranacional da matéria. A atual base jurídica da política migratória está prevista nos artigos 79 e 80 do Tratado de Funcionamento da UE (TFUE), visando estabelecer uma política europeia virada para o futuro em matéria de migração, baseada na solidariedade, estabelecendo uma abordagem equilibrada no tratamento tanto da imigração regular como da irregular ${ }^{36}$. Para a UE, uma gestão adequada dos fluxos migratórios implica garantir tratamento justo aos nacionais de países terceiros que residem legalmente no bloco, aperfeiçoar medidas de combate à imigração irregular e promover cooperação mais estreita com países terceiros.

\footnotetext{
34 VALENTE, Isabel; GUIA, Maria. As políticas europeias de imigração: breve abordagem ao caso português. Anos 90, Porto Alegre, v. 23 , n. 43, p. 39-65, 2016. Disponível em: https://seer.ufrgs.br/ index.php/anos90/article/view/62515 Acesso em: 30 maio 2021.

35 VIEIRA, Luciane; COSTA, Vitória. A resposta comum da UE frente à pandemia de COVID-19 e os compromissos com a proteção internacional dos direitos humanos de imigrantes e refugiados. In: BAENINGER, Rosana; VEDOVATO, Luís; NANDY Shailen (coord.). Migrações internacionais e a pandemia de Covid-19. Campinas: Nepo/Unicamp, 2020. p. 232-254. p. 236.

36 PARLAMENTO EUROPEU. Politica de imigração. 2021. Disponível em: www.europarl.europa.eu/factsheets/pt/sheet/152/ politica-de-imigracao Acesso em: 29 abr. 2021.
}

Em relação à gestão da migração regular, compete à UE definir as condições de admissão e de residência legal num Estado-membro para os nacionais de países terceiros, enquanto os Estados-membros conservam o direito de determinar o volume de admissão de pessoas provenientes de países terceiros à procura de emprego. Em matéria de integração dos imigrantes a comunidades de destino, a UE pode incentivar e apoiar as medidas adotadas pelos Estados do bloco. No que tange ao disciplinamento da migração regular, a atual disciplina normativa da UE se pauta em uma setorização no quadro normativo, decorrente de um complexo e fragmentário conjunto de normativas que disciplinam a política de imigração, cujas normas direcionam-se a categorias específicas de imigrantes, para atrair e selecionar certos fluxos, tais como trabalhadores altamente qualificados; trabalhadores sazonais; profissionais transferidos em empresas e deslocamentos para fins de estudo e pesquisa $^{37}$.

Em termos de imigração irregular, a UE tem competência para prevenir e reduzir tal fluxo, em especial através de uma política de regresso eficaz. Ainda, a UE tem competência para celebrar acordos de readmissão de imigrantes com países terceiros, no país de origem ou de proveniência, de nacionais de países terceiros que não preencham ou tenham deixado de preencher as condições de admissão, presença ou residência em um Estado-membro. As normativas centram-se no endurecimento das fronteiras externas e na realização de operações nos Estados-membros expostos a um afluxo desproporcional de pessoas ${ }^{38}$, bem como na cooperação com países terceiros para devolução de imigrantes em situação de irregularidade, em um paradigma cada vez mais externalizado da política migratória do bloco. Como resultado, tem-se a prevalência de uma abordagem defensiva, centrada no reforço das fronteiras e na contenção da imigração não documentada, em que as estratégias da UE para os fluxos irregulares apostam na adoção de controles fronteiriços rigorosos, que impedem a entrada desses sujeitos migrantes no bloco, e em uma política de regresso eficaz, que se pauta na retirada dos indesejados do espaço europeu, enviando-os para países terceiros.

\footnotetext{
${ }_{37}$ CARRERA, Sergio et al. The Cost of Non-Europe in the Area of Legal Migration. CEPS paper in liberty and security in Europe. Bruxelas: CEPS, 2019, p. 5.

38 FERREIRA, Susana. Human security and migration in Europe's southern borders. Cham: Palgrave Macmillan, 2019.
} 
Os resquícios de uma abordagem migratória restritiva em relação a imigrantes de terceiros Estados ainda estão presentes, sobretudo no disciplinamento das migrações irregulares. Isso porque, no bloco europeu, como consequência do longo processo de fragilização das fronteiras internas e de facilitação dos fluxos de pessoas entre os Estados-membros, observou-se "O surgimento de uma fronteira externa comum e um recrudescimento das políticas de acesso de pessoas originadas de fora do contexto europeu", como aponta Veloso ${ }^{39}$, principalmente no que tange à gestão dos fluxos irregulares.

O tratamento da imigração irregular está previsto tanto nos tratados estruturantes do bloco, quanto no direito derivado. Desde o TFUE, nos artigos 79 e 80, reconhece-se que a política comum de imigração se baseia na prevenção da imigração irregular, permitindo-se a adoção de medidas voltadas ao combate à imigração não autorizada e à residência irregular, incluindo o afastamento e o repatriamento de residentes nessa situação, bem como autorizando a UE a celebrar com países terceiros acordos destinados à readmissão, nos países de origem ou de proveniência, de nacionais de países terceiros que não preencham ou tenham deixado de preencher as condições de entrada, de presença ou de residência nos Estados-membros ${ }^{40}$.

A ideia de imigração irregular, por seu turno, frequentemente indica o movimento de pessoas que ocorre fora das leis, regulamentos ou acordos internacionais que regem a entrada ou saída do Estado de origem, trânsito ou destino ${ }^{41}$. Não obstante exista uma pluralidade de termos estigmatizantes como "migração clandestina" ou "ilegal", o termo é usado para identificar pessoas que se deslocam fora das vias regulares de migração, muito embora o fato de imigrarem de forma irregular, não autorizada ou não documentada, não exima completamente o Estado da obrigação de tutelar seus direitos quando ingressam no território nacional ou no espaço regional.

\footnotetext{
39 VELOSO, Paulo. Da União à fortaleza ou como a relação de dependência entre migração e integração podem fazer desaparecer a ideia de União Europeia. Revista da Faculdade de Direito da UFMG, Belo Horizonte, n. 75, p. 467-485, 2019. Disponível em: https://revista.direito.ufmg.br/index.php/revista/article/view/2031 Acesso em: 02 jun. 2021.

40 PARLAmento EUROPEU. Política de imigração. 2021. Disponível em: www.europarl.europa.eu/factsheets/pt/sheet/152/ politica-de-imigracao Acesso em: 29 abr. 2021.

${ }^{41}$ INTERNATIONAL ORGANIZATION FOR MIGRATION. Glossary on migration. Genebra: IOM, 2019. p.116.
}

No caso da UE, a abordagem restritiva a respeito desses fluxos migratórios corresponde a uma linha de argumentação que identifica a política comum de imigração com uma política de combate à imigração irregular. A migração irregular, por um lado, pode ser vista pelos governos como causa do subdesenvolvimento, levando a movimentos migratórios caóticos, irresponsáveis e ineficazes, resultando em um impacto negativo nos países de origem ${ }^{42}$, mas, também, nos países de recepção, sobrecarregando os sistemas nacionais. Por outro lado, a irregularidade migratória é muitas vezes tratada como um risco ou ameaça ao espaço comum europeu, que pode se converter em ameaças à segurança, à ordem pública ou aos mercados laborais internos.

Por meio dessas interações, a política de luta contra a imigração irregular na Europa continua sendo reforçada. Sobretudo em contextos de crise, as fragilidades do modelo europeu de disciplinamento são postas à prova. Fomenta-se a ideia de que as fronteiras externas da UE estão ameaçadas pela migração irregular e que devem ser protegidas por meio da utilização de meios tecnológicos sofisticados, como as operações de vigilância, cooperação com países terceiros para monitoramento de fronteiras, reenvio de imigrantes em situação de irregularidade, treinamento conjunto de guardas de fronteiras e uso de bases de dados para identificar potenciais ameaças, com auxílio de agências especializadas, razão pela qual a política de imigração restritiva é ela mesma geradora da ilegalidade que se pretende combater.

No âmbito da UE, a prevenção e o combate à migração irregular é, para os Estados-membros do bloco, um direito, defendido em nome da autodeterminação nacional, e um dever, reconhecido pela política comum de imigração ${ }^{43}$. Dentre as principais normativas da política de imigração da UE para os imigrantes em situação de irregularidade, que ilustram a abordagem defensiva até então praticada, destaca-se a Diretiva Regresso 2008/115/CE ${ }^{44}$ que define procedimentos comuns nos

\footnotetext{
42 LAUWERS, Nathan; ORBIE, Jan; DELPUTTE, Sarah. The politicization of the migration-development nexus: parliamentary discourse on the European Union trust fund on migration. Journal of Common Market Studies, v. 59, n. 1, p. 72-90, 2021. Disponível em: https://onlinelibrary.wiley.com/doi/full/10.1111/jcms.13140. Acesso em 02 jun. 2021.

${ }^{43}$ CARVALHO, Felipe. Criminalização de imigrantes ilegais na União Europeia: novos paradigmas com base no caso Celaj. Revista de Direito Internacional, Brasília, v. 16, n. 1, p. 252-268, 2019. Disponível em: https://publicacoesacademicas.uniceub.br/rdi/article/ view/5956 Acesso em: 31 maio 2021.

${ }^{44}$ COMISSÃO EUROPEIA. Directiva 2008/115/CE do Parlamento
} 
Estados-membros para o regresso de nacionais de países terceiros em situação irregular.

A referida diretiva define o regresso como o processo de retorno de nacionais de países terceiros, a título de cumprimento voluntário de um dever de regresso ou a título coercivo: ao país de origem; a um país de trânsito, ao abrigo de acordos de readmissão comunitários ou bilaterais; ou mesmo a outro país terceiro, para o qual a pessoa em causa decida regressar voluntariamente e no qual seja aceite. Portanto, a diretiva em questão ilustra a existência de uma política regional para o regresso de nacionais de países terceiros em situação de irregularidade no espaço comum.

A normativa em comento, por seu turno, revela uma iniciativa incisiva no enfrentamento da imigração irregular porque "contém disposições relativas à utilização da força pelos Estados-membros para proceder à remoção de imigrantes em situação irregular", como aponta Carvalho $^{45}$. Particularmente, questionam-se os mecanismos de detenção para efeitos de afastamento dos imigrantes irregulares, um dos aspectos mais controvertidos da Diretiva, que pode reforçar um processo de criminalização dos fluxos migratórios não autorizados.

Do ponto de vista da jurisprudência europeia, o TJUE adotava posição que interpretava a Diretiva Regresso segundo critérios que impediam a adoção de penas privativas de liberdade para imigrantes irregulares, como se observa, por exemplo, no caso El Dridi ${ }^{46}$, em que o Tribunal considerou que a Diretiva em questão impedia a aplicação de uma pena de prisão aos migrantes irregulares durante a execução da decisão de regresso. No entanto, em julgados mais recentes, a exemplo do caso Celaj ${ }^{47}$, o TJUE apresentou uma perspectiva

Europen e do Conselho. 2008. Disponível em: https://eur-lex.europa. $\mathrm{eu} /$ legal-content/PT/TXT/?uri=CELEX\%3A32008L0115 Acesso em: 31 maio 2021.

45 CARVALHO, Felipe. Criminalização de imigrantes ilegais na União Europeia: novos paradigmas com base no caso Celaj. Revista de Direito Internacional, Brasília, v. 16, n. 1, p. 252-268, 2019. Disponível em: https://publicacoesacademicas.uniceub.br/rdi/article/ view/5956 Acesso em: 31 maio 2021.

${ }^{46}$ UNIÃO EUROPEIA. Tribunal de Justiça da União Europeia. Caso El Dridi (C-61/11). Acórdão de 28 abril 2011. Disponível em: curia.europa.eu/juris/document/document.jsf?text $=\&$ docid $=8203$ $8 \&$ pageIndex $=0 \&$ doclang $=$ pt\&mode $=1 \mathrm{st} \& \operatorname{dir}=\& o c c=$ first $\&$ part $=$ 1\&cid=767654 Acesso em: 30 jun. 2021.

47 UNIÃO EUROPEIA. Tribunal de Justiça da União Europeia. Caso Celaj (C-290/14). Acórdão de 1 outubro 2015. Disponível em: curia.europa.eu/juris/document $/$ document.jsf?text $=\&$ docid $=1689$ 41 \&pageIndex $=0 \&$ doclang $=p t \&$ mode $=1$ st $\& \operatorname{dir}=\& o c c=$ first \&part de mudança em sua linha interpretativa, ao decidir que a Diretiva em análise não se opõe, em princípio, à regulamentação de um Estado-membro que impõe uma pena de prisão a um nacional de um país terceiro que entre irregularmente no seu território em violação de uma proibição de entrada. Como resultado, tem-se uma perspectiva de recrudescimento na gestão da migração irregular na UE, como uma resposta ao influxo massivo de migrantes nas fronteiras externas, o que revela a função da normativa como um instrumento para favorecer a retirada de imigrantes irregulares, através de acordos de readmissão e procedimentos de regresso.

Para viabilizar tais acordos de readmissão e os mecanismos de regresso, a política de imigração europeia se baseia em um paradigma cada vez mais externalizado de cooperação com países terceiros e de reforço de fronteiras externas. Os Estados, em cooperação com outros Estados e organizações, adotam estratégias para evitar que migrantes entrem em seus territórios ou para impedi-los de deixar seus países de origem ou trânsito. As parcerias são variadas e visam estabelecer zonas de amortecimento; fortalecer controles de fronteira; e estabelecer acordos gerais de readmissão ou admissão para receber imigrantes ${ }^{48}$.

As formas de cooperação incluem financiamento; fornecimento de treinamento, equipamento ou suporte técnico; e destacamento de oficiais para operações conjuntas em países de trânsito, em troca de o país terceiro concordar em admitir os sujeitos em mobilidade. Como explica Ferstman ${ }^{49}$, tais acordos proliferaram, buscando aumentar a colaboração com outros países, a exemplo da Turquia, Líbia e outros países do norte da África e da África subsaariana na rota de migração do Mediterrâneo Central.

Recentemente, as inovações normativas do bloco continuam apostando em estratégias defensivas, focadas no combate à irregularidade como uma prioridade da política migratória da UE. Nesse sentido, destaca-se o Novo Pacto da Migração e Asilo, como se abordará

=1\&cid=758346 Acesso em: 30 jun. 2021.

48 COMISSÃO EUROPEIA. Return \& readmission: migration and home affairs. 2021. Disponível em: https://ec.europa.eu/homeaffairs/what-we-do/policies/irregular-migration-return-policy/ return-readmission_en Acesso em: 06 jun. 2021.

49 FERSTMAN, Carla. Human rights due diligence policies applied to extraterritorial cooperation to prevent "irregular" migration: European Union and United Kingdom Support to Libya. German Law Journal, v. 21, n. 3, p. 459-486, 2020. Disponível em: https://bit. ly/3wNeR4u Acesso em: 02 jun. 2021. 
no tópico seguinte, que se apresenta como um pacto renovado para a gestão de antigos desafios da política de imigração europeia, mas que não rompe significativamente com a lógica de enfrentamento da irregularidade migratória apresentada nesta seção.

\section{0 disciplinamento normativo dos fluxos migratórios irregulares à luz do Novo Pacto Europeu sobre Migração e Asilo}

Dentre as iniciativas recentes que buscam implementar uma gestão migratória mais eficiente no contexto da UE, destaca-se a aprovação do já mencionado Novo Pacto Europeu para Migrações e Asilo ${ }^{50}$. O Pacto foi adotado em setembro de 2020, pela Comissão Europeia, e se apresenta como uma solução para a política de imigração do bloco, propondo procedimentos melhorados no sistema regional, a fim de restabelecer o equilíbrio entre a solidariedade e a partilha de responsabilidades entre os membros da UE.

Dentre os fatores que explicam o contexto de surgimento do Pacto, Geddes ${ }^{51}$ aponta, primeiramente, o fracasso das soluções anteriores em fornecer uma resposta unificada da UE nesta matéria. A crise migratória de 2015 expôs divisões entre os Estados-membros que ainda não foram sanadas, principalmente devido à partilha desigual de responsabilidades na gestão migratória. Ademais, aponta-se o desejo, por parte da Comissão Europeia, de normalizar o debate sobre a migração, e de afastá-lo de uma narrativa de crise. Para tanto, buscou-se encontrar novo equilíbrio entre os Estados-membros, com uma solidariedade que envolve participações dos Estados nos procedimentos de regresso de imigrantes, sem a obrigatoriedade de acolhida.

Como acentua Pichon ${ }^{52}$, a Comissão Europeia propôs um novo pacto sobre migração e asilo para reforçar

50 COMISSÃO EUROPEIA. Comunicação da Comissão sobre um novo Pacto em matéria de Migração e Asilo. 2020. Disponível em: https:/ / eur-lex. europa.eu/legal-content/PT/TXT/?uri=CELEX:52020DC0609 Acesso em: 30 abr. 2021.

51 GEDDES, Andrew. The European Pact on Migration and Asylum. Imiscoe Bulletin, editorial, dez. 2020. Disponível em: https:// www.imiscoe.org/news-and-blog/bulletin/bulletin-3/1162-theeuropean-pact-on-migration-and-asylum Acesso em: 01 jun. 2021.

52 PICHON, Eric. The external dimension of the new pact on migration and asylum: a focus on prevention and readmission. a solidariedade entre os Estados-Membros e para reforçar a gestão da migração e os procedimentos de asilo da UE. O escopo do Pacto reside em fomentar uma política migratória, pretensamente renovada, em que as necessidades criadas pelas chegadas irregulares de migrantes e requerentes de asilo não sejam tratadas pelos Estados-membros individualmente, mas pela UE no seu conjunto. Acerca dessa noção de solidariedade buscada na política migratória europeia, e reafirmada no Pacto em referência, o próprio TJUE já teve oportunidade de se pronunciar no bojo do acórdão ${ }^{53}$ proferido nos processos apensos C-715/17, C-718/17 e C-719/17, envolvendo, respectivamente, a Comissão Europeia contra a Polônia, Hungria e República Checa em matéria de recolocações. No acórdão citado, reconheceu-se que a solidariedade implica que todos os Estados-membros devem contribuir com a política migratória do bloco. Em consequência, o novo Pacto é lançado em um contexto em que a legislação europeia e a jurisprudência comunitária buscam envolver os Estados-membros na gestão das migrações, em uma tentativa de fornecer alternativas à questão migratória na Europa.

No entanto, apesar de o referido Pacto pretender dar um novo começo à política migratória da UE, a proposta continua priorizando o combate à irregularidade como uma das principais ações na gestão das migrações. Como observado na seção anterior, as soluções apresentadas pelo direito europeu para contenção dos fluxos irregulares produziram normativas focadas no reforço de fronteiras externas, visando impedir a entrada de novos fluxos, bem como nas operações de regresso e nos acordos de readmissão, objetivando a retirada dos imigrantes em situação de irregularidade no espaço comum.

O Pacto representa, portanto, um objeto de análise fundamental para o presente artigo porque a referida iniciativa comunitária coloca ênfase no disciplinamento das migrações irregulares, fixando como um dos seus objetivos a consolidação de um sistema europeu em matéria de regresso. Em sua dimensão externa, o Pacto visa reforçar parcerias internacionais, a fim de garantir

European Parliament Think Tank, 2021. Disponível $\square$ em: $\square$ www. europarl.europa.eu/RegData/etudes/BRIE/2021/690535/EPRS_ BRI(2021)690535_EN.pdf Acesso em: 02 jun. 2021.

53 UNIÃO EUROPEIA. Tribunal de Justiça da União Europeia. Acórdão nos processos apensos C-715/17, C-718/17 e C-719/17. Acórdão de 2 abril 2020. Disponível em: https://bit.ly/3hb2b2L Acesso em: 02 jul. 2021. 
retornos eficazes, combater máfias de atravessadores e enfrentar a irregularidade migratória.

Tais estratégias expostas no novo Pacto, por sua vez, têm sido criticadas por representarem uma continuação da política de luta contra a migração irregular aplicada ao bloco, estigmatizando indivíduos em categorias de regularidade e irregularidade migratória. Em linhas gerais, a iniciativa da Comissão, as recomendações e as propostas legislativas que a acompanham colocam menos ênfase nos canais legais para migração do que em medidas destinadas a incentivar países terceiros a reter migrantes irregulares ou a aceitar o regresso das pessoas em situação de irregularidade na UE.

A partir desse contexto de análise, a presente seção busca responder ao questionamento sobre se o referido Pacto constitui uma efetiva inovação normativa no direito da UE rumo a uma política comum de imigração, ou se, ao contrário, reforça as estratégias até então praticadas, voltadas ao combate à irregularidade migratória, em detrimento de uma efetiva política regional de regularização, de integração dos imigrantes extracomunitários e de enfrentamento das causas profundas que geram os fluxos irregulares.

Ao lançar o novo Pacto sobre Migração, a Comissão Europeia apresentou um amplo pacote de propostas e regulamentações que abrangem os vários elementos necessários para uma abordagem europeia do tema. No entanto, considerando-se os limites metodológicos do artigo, a análise se concentra nas inovações propostas em matéria de gestão das migrações irregulares, com o intuito de analisar se o novo Pacto mantém ou inova a política de imigração defensiva até então praticada em relação aos fluxos não autorizados, notadamente nos procedimentos de regresso, no reforço de fronteiras externas e na cooperação com países terceiros.

Diante das perspectivas trazidas pelo Pacto, a primeira inovação identificada consiste na adoção do chamado sistema de patrocínio de regresso. O sistema indica uma espécie de patrocínio de expulsão de imigrantes irregulares na UE, mediante o qual um Estado-membro assume a responsabilidade pelo regresso de um nacional de país terceiro sem direito a permanecer na UE em nome de outro Estado-membro ${ }^{54}$. A opção de patro-

${ }^{54}$ COMISSÃO EUROPEIA. Novo pacto em matéria de migração e asilo: uma nova abordagem em matéria de migração na Europa. 2021. Disponível em: https://ec.europa.eu/info/strategy/priorities-2019-2024/promoting-our-european-way-life/new-pact-migra- cínio de regresso implica no oferecimento de opções flexíveis para as contribuições dos Estados-membros que se recusem a receber imigrantes em seus territórios nacionais, a fim de implementar um novo mecanismo para assegurar uma solidariedade constante, que pode abarcar, ainda, o apoio operacional, a partir do reforço das capacidades em matéria de procedimentos de asilo, acolhimento de recém-chegados ou operações de regresso, bem como a assistência na resposta as tendências migratórias que afetem os demais membros.

Em relação ao patrocínio de regressos, os Estados-membros devem prestar todo o apoio necessário ao Estado-membro sob pressão para fazer regressar rapidamente quem não tiver direito de permanência, assumindo o Estado que presta apoio a responsabilidade se o regresso não for efetuado ${ }^{55}$. Em vez de receber os imigrantes, os países membros relutantes podem patrocinar a retirada de migrantes irregulares, custeando o processo em outro Estado. Em situações de crise ou de força maior, o Pacto prevê a realocação obrigatória de candidatos sob proteção internacional ou a opção pelos patrocínios de retorno ${ }^{56}$.

O mecanismo proposto reforça um modelo já praticado na UE de combate aos fluxos migratórios irregulares. $\mathrm{O}$ foco da abordagem permanece na retirada dos imigrantes irregulares do espaço comum, em detrimento de uma política de regularização e de enfrentamento das causas profundas do fenômeno. Na verdade, a normativa propõe repartir encargos de um Estado-membro a outro no processo de transferência, em vez de buscar uma realocação efetiva do imigrante, o que reforça a política defensiva observada.

Sob o aporte jurídico, o sistema apresentado pode ser problemático para a implementação de uma política europeia consentânea com a efetiva proteção dos direitos fundamentais da pessoa migrante. As razões legítimas dos indivíduos para ficar ou partir não são levadas em consideração no contexto de realocação ou devolução de patrocínios. Em outras palavras, o mecanismo de solidariedade proposto para as migrações irregulares corre o risco de ser usado como um instrumento de

tion-and-asylum_pt Acesso em: 29 maio 2021.

55 COMISSÃO EUROPEIA. Comunicaşão da Comissão sobre um novo Pacto em matéria de Migração e Asilo. 2020. Disponível em:https:/ / eur-lex. europa.eu/legal-content/PT/TXT/?uri=CELEX:52020DC0609 Acesso em: 30 abr. 2021.

56 CARRERA, Sergio. Whose Pact?: the cognitive dimensions of the new EU Pact on Migration and Asylum. Bruxelas: CEPS, 2020. p. 7. 
barganha entre os Estados-membros para se furtarem à cooperação regional ou consentirem com interesses políticos nacionais, em que a moeda de troca utilizada pelos países se torna o próprio sujeito migrante.

Outra inovação normativa do Pacto europeu para migração e asilo, que afeta o disciplinamento das migrações irregulares, diz respeito ao reforço dos procedimentos de controle nas fronteiras externas da UE, a partir dos procedimentos de triagem antes da entrada e da reafirmação de competências das agências responsáveis pela gestão fronteiriça no bloco.

Por um lado, os procedimentos de triagem incluem a identificação, os controles sanitários e de segurança, e a recolha de impressões digitais dos nacionais de países terceiros ${ }^{57}$. O novo modelo pode enrijecer os procedimentos de controle migratório, ao permitir o bloqueio dos deslocamentos que não preencham imediatamente os requisitos de mobilidade do direito da UE. Por outro lado, o protagonismo conferido às agências europeias especializadas na gestão fronteiriça, a exemplo da Agência Europeia da Guarda de Fronteiras e Costeira (FRONTEX), também revela o propósito de incrementar o enfrentamento à imigração irregular ${ }^{58}$. $\mathrm{O}$ novo Pacto reconhece que a FRONTEX desempenha papel crucial para prestação de assistência operacional aos Estados-membros expostos a situações de pressão migratória, razão pela qual reconhece que a agência deve desempenhar um papel de liderança no sistema comum de regresso, tornando-se a vertente operacional da política de regresso de imigrantes em situação de irregularidade, com a nomeação de um diretor executivo adjunto para este domínio.

Noutro giro, o Pacto coloca uma considerável ênfase nas parcerias com países terceiros, sobretudo para efetivar os procedimentos de regresso de imigrantes em situação de irregularidade. A proposta busca contribuir para uma política externa abrangente, pautada na parceria com Estados terceiros, transferindo a responsabilidade de acolhimento dos sujeitos em mobi-

57 COMISSÃO EUROPEIA. Comunicaşão da Comissão sobre um novo Pacto em matéria de Migração e Asilo. 2020. Disponível em: https: / / eur-lex. europa.eu/legal-content/PT/TXT/ ?uri=CELEX:52020DC0609 Acesso em: 30 abr. 2021.

58 STEFAN, Marco; CORTINOVIS, Roberto. Setting the right priorities: is the New Pact on Migration and Asylum addressing the issue of pushbacks at EU external borders? In: CARRERA, Sergio; GEDDES, Andrew (eds.). The EU Pact on Migration and Asylum in light of the United Nations Global Compact on Refugees. Florença: EUI, 2021. p. 180-194. p. 187. lidade para tais países. O Pacto depende, fortemente, de instrumentos de cooperação internacional centrados na externalização, o que coloca a gestão migratória no centro das relações externas da UE. Tais instrumentos assumem a forma de parcerias para a migração, que são acordos com países terceiros, voltados à readmissão de imigrantes, sendo acompanhados de instrumentos de financiamento e priorizando os regressos, as expulsões e o controle fronteiriço.

Nesse ponto, o Pacto reconhece que a readmissão deve ser um elemento indispensável das parcerias internacionais de gestão migratória ${ }^{59}$, o que representa uma posição política de longa data no bloco europeu. As parcerias de migração da UE buscam favorecer o retorno de imigrantes irregulares para países terceiros, oferecendo a tais países facilitação de vistos, liberalização de mobilidades, cooperação para o desenvolvimento e até mesmo aporte de investimentos, em troca da colaboração prestada. No entanto, diante de eventual recusa de cooperação, o Pacto prevê a possibilidade de aplicação de medidas restritivas de visto aos nacionais de países que não ajudem na readmissão, o que, mais uma vez, implica uma espécie de barganha com países terceiros para colaborarem com a política de regresso da UE.

Em linhas gerais, como observado, as propostas normativas do novo Pacto focam na implementação de um sistema de patrocínios de regresso, no reforço de fronteiras externas e na cooperação com países terceiros, numa tentativa de blindar a UE de movimentos migratórios não autorizados ou desconformes com o direito comunitário. Ocorre que tais estratégias, como apontado na seção anterior, já norteavam as ações da UE. O que o Pacto propõe parece menos uma ruptura jurídica com a estratégia de contenção da irregularidade migratória e mais uma tentativa de reequilibrar os princípios de solidariedade e de partilha de responsabilidades entre os Estados-membros, o que acaba por confirmar uma política de imigração restritiva e defensiva em relação aos nacionais de países terceiros, que já vinha sendo praticada na UE.

A despeito de ter sido apresentada como um "novo começo", a nova política migratória corre o risco de aumentar muros e reforçar cercas, fomentando a permanência de uma abordagem restritiva e defensiva em

59 CARRERA, Sergio. Whose Pact?: the cognitive dimensions of the new EU Pact on Migration and Asylum. Bruxelas: CEPS, 2020. p. 10 . 
relação aos nacionais de países terceiros. Como sugere Bendel $^{60}$, em vez de representar "um novo começo", o Pacto reedita escolhas políticas e jurídicas bem conhecidas, embora às vezes com uma aparência de novidade. Em vez de apresentar uma nova ideia de solidariedade, baseia-se mais na lógica de soluções flexíveis pautadas em interesses nacionalistas.

No caso da UE, a abordagem defensiva e restritiva da migração, em larga medida reforçada pelo Pacto analisado, materializa-se em um paradigma cada vez mais externalizado da política migratória, a partir da aposta no combate à imigração irregular, ainda encarada como uma ameaça à integração europeia. Essa posição reflete na adoção de critérios jurídicos rigorosos para a mobilidade humana, representados na reintrodução de barreiras para os fluxos considerados indesejados, o que alimenta a dicotomia entre a lógica estatal de enrijecimento das migrações, de um lado, e a necessidade da mobilidade humana calcada no paradigma transnacional, de outro.

As normativas analisadas indicam que o sistema europeu tem se pautado em uma política migratória restritiva, com um investimento sem precedentes no controle das fronteiras externas ${ }^{61}$, que tem levado a uma integração defensiva ${ }^{62}$ na seara migratória. $O$ resultado é um modelo integrativo ancorado em soluções incisivas para o gerenciamento do fluxo extracomunitário, sobretudo em relação aos fluxos irregulares.

Constata-se que o novo Pacto reforça a lógica defensiva da imigração, não havendo ruptura com as políticas migratórias até então praticadas na UE, o que confirma a hipótese de pesquisa inicialmente aventada. O Pacto coloca em relevo posições que focam o combate à irregularidade como um dos principais objetivos das normativas europeias, reforçando uma percepção da imigração como um processo que pode ser travado

60 BENDEL, Petra. Fresh start or false start?: the new Pact on Migration and Asylum. In: CARRERA, Sergio; GEDDES, Andrew (eds.). The EU Pact on Migration and Asylum in light of the United Nations Global Compact on Refugees. Florença: EUI, 2021. p. 251-261. p. 258.

${ }^{61}$ SCHIMMELFENNIG, Frank. Rebordering Europe: external boundaries and integration in the European Union. Journal of European Public Policy, v. 28, n. 3, p. 311-330, 2021. Disponível em: www. tandfonline.com/doi/full/10.1080/13501763.2021.1881589 Acesso em: 28 maio 2021.

62 KRIESI, Hanspeter et al. Debordering and re-bordering in the refugee crisis: a case of 'defensive integration'. Journal of European Public Policy, v. 28, n. 3, p. 331-349, 2021. Disponível $\square$ em: $\square$ www. tandfonline.com/doi/full/10.1080/13501763.2021.1882540 Acesso em: 06 jun. 2021. através de controles rigorosos nas fronteiras exteriores, visando o incremento da dimensão externa da política migratória.

Nesse ponto, entende-se que uma política migratória focada no combate à irregularidade pode se mostrar problemática sob o aspecto jurídico porque contribui para o estigma e categorização de indivíduos, associados a uma condição jurídica diferenciada, cujo tratamento varia a depender do respectivo status migratório de ingresso e permanência no espaço comum, o que pode inviabilizar o gozo de direitos assegurados no âmbito regional às demais categorias de imigrantes. Ademais, o foco no enrijecimento de fronteiras externas pode contribuir para criminalizar condutas relacionadas aos processos migratórios, dificultando o exercício do direito de migrar e o acesso aos direitos fundamentais daqueles que se deslocam em busca de proteção internacional ou de melhores condições econômicas. Ainda, o foco no endurecimento das fronteiras externas e no combate aos deslocamentos não autorizados pode contribuir para gerar ainda mais irregularidade, por meio da criação de rotas alternativas e cada vez mais perigosas para driblar os sistemas de controle.

Frise-se, por fim, que não se está necessariamente a criticar todos os objetivos propostos pelo Pacto, que apresenta aspectos positivos, a exemplo da referência a compromissos globais de proteção a refugiados ${ }^{63}$. Mas, é preciso destacar que, em matéria de irregularidade migratória, a estratégia proposta acentua medidas já aplicadas na UE que acabam por refletir uma luta contra o próprio imigrante. Em vez de uma política efetiva de regularização, opta-se pela expulsão do espaço comum, proíbe-se a reentrada, arrisca direitos fundamentais, além de dificultar o acompanhamento desses direitos nos países que repatriam imigrantes no bojo dos acordos de readmissão. Em vez de uma abordagem focada nas causas profundas das migrações irregulares, com investimentos responsáveis, construção de diálogo conjunto para solução pacífica das controvérsias e adoção de uma política efetiva de regularização, prefere-se apostar no regresso e no reforço fronteiriço.

Conclui-se, da presente análise, que o referido Pacto, apesar de se apresentar como novo, de fato, não é. O que está proposto é uma remodelação dos procedi-

63 CARRERA, Sergio. Whose Pact?: the cognitive dimensions of the new EU Pact on Migration and Asylum. Bruxelas: CEPS, 2020. p. 10. 
mentos para construção de um sistema mais eficiente de gestão migratória, que busca estimular maior solidariedade entre os Estados-membros da UE, mas sem romper com a essência da política de combate à irregularidade até então praticada, confirmando a hipótese inicial da pesquisa.

\section{Considerações finais}

O processo de integração regional, sobretudo em suas etapas mais avançadas, conduz à criação de um centro normativo de disciplinamento da mobilidade humana. O regime de regulamentação migratória, em arranjos integrativos, tende a favorecer os deslocamentos intrarregionais, com base na concessão de prerrogativas de circulação e residência para os cidadãos do bloco, enquanto busca enrijecer e selecionar os deslocamentos extrarregionais, principalmente em relação aos fluxos migratórios irregulares.

O modelo dual de disciplinamento das migrações em espaços comuns pode ser observado, com mais notoriedade, no âmbito da UE, cujo processo integrativo evoluiu para formação de um espaço de livre circulação de pessoas no interior do bloco, ao passo que, externamente, busca-se reforçar os controles fronteiriços e migratórios. As normativas adotadas pela UE evoluíram no sentido de estabelecer uma política de imigração para o bloco, pautada na solidariedade entre os membros e na partilha equitativa de responsabilidades.

Sobre o regime jurídico aplicável às migrações extracomunitárias na UE, o artigo constatou que a política europeia de imigração se pautou em uma abordagem restritiva para o disciplinamento das migrações consideradas irregulares à luz do direito da UE. Constata-se que o referido modelo está centrado nas operações de regresso e em acordos celebrados com países terceiros para readmissão de imigrantes em condição irregular, com respostas restritivas em face da tentativa de contenção dos fluxos não autorizados.

Dentre as normativas comunitárias analisadas, o artigo verificou que o Novo Pacto Europeu para as Migrações e Asilo representa uma das principais iniciativas da UE na busca por uma solução regional para a mobilidade humana. Observou-se que o Pacto, apesar de pretender um novo começo na gestão migratória até então aplicada, tão somente reforça as estratégias jurí- dicas regionais voltadas à contenção da irregularidade. Em matéria de imigração irregular, constata-se que o Pacto buscou instituir um sistema comum de regressos, que foca no reenvio de imigrantes em situação de irregularidade a países terceiros e no reforço de fronteiras externas.

A partir da análise normativa, portanto, é possível confirmar a hipótese aventada de que o novo Pacto não representa uma ruptura jurídica significativa com a política migratória até então reconhecida. Pelo contrário. O Pacto reforça mecanismos de regresso, readmissão e reforço das fronteiras externas como alternativas à irregularidade migratória. Como resultado, tem-se um sistema que busca impedir ou reduzir significativamente o acesso de alguns imigrantes ao espaço europeu, o que evidencia a permanência, em larga medida, de uma política migratória defensiva, centrada na contenção da irregularidade, em detrimento do enfrentamento das causas profundas geradoras de fluxos irregulares e da adoção de políticas efetivas de regularização e de acolhimento com base nas capacidades reais de cada Estado-membro.

\section{Referências}

ACOSTA, Diego. Global migration law and regional free movement: compliance and adjudication. American Journal of International Law, v. 111, p. 159-164, 2017. Disponível em: https://bit.ly/3d81YJe Acesso em: 30 jun. 2021.

BALASSA, Bela. Teoria da integração econômica. Lisboa: Livraria Clássica, 1961.

BENDEL, Petra. Fresh start or false start?: the new Pact on Migration and Asylum. In: CARRERA, Sergio; GEDDES, Andrew (eds.). The EU Pact on Migration and Asylum in light of the United Nations Global Compact on Refugees. Florença: EUI, 2021. p. 251-261.

BORZEL, Tanja. Theorizing regionalism: cooperation, integration, and governance. In: BORZEL, Tanja; RISSE, Thomas (eds.). The Oxford Handbook on Comparative Regionalism. Oxford: Oxford University Press, 2016.

CARRERA, Sergio et al. The cost of non-europe in the area of legal migration: CEPS paper in liberty and security in Europe. Bruxelas: CEPS, 2019. 
CARRERA, Sergio. Whose Pact?: the cognitive dimensions of the new EU Pact on Migration and Asylum. Bruxelas: CEPS, 2020.

CARVALHO, Felipe. Criminalização de imigrantes ilegais na União Europeia: novos paradigmas com base no caso Celaj. Revista de Direito Internacional, Brasília, v. 16, n. 1, p. 252-268, 2019. Disponível em: https://publicacoesacademicas.uniceub.br/rdi/article/view/5956 Acesso em: 31 maio 2021.

COMISSÃO EUROPEIA. Comunicação da Comissão sobre um novo Pacto em matéria de Migração e Asilo. 2020. Disponível em: https://eur-lex.europa.eu/legal-content/ PT/TXT/?uri=CELEX:52020DC0609 Acesso em: 30 abr. 2021.

COMISSÃO EUROPEIA. Directiva 2008/115/CE do Parlamento Europen e do Conselho. 2008. Disponível em: https://eur-lex.europa.eu/legal-content/PT/ TXT/?uri=CELEX\%3A32008L0115 Acesso em: 31 maio 2021.

COMISSÃO EUROPEIA. Novo pacto em matéria de migraşão e asilo: uma nova abordagem em matéria de migração na Europa. 2021. Disponível em: https:// ec.europa.eu/info/strategy/priorities-2019-2024/ promoting-our-european-way-life/new-pact-migrationand-asylum_pt Acesso em: 29 maio 2021.

COMISSÃO EUROPEIA. Return \& readmission: migration and home affairs. 2021. Disponível em: https:// ec.europa.eu/home-affairs/what-we-do/policies/irregular-migration-return-policy/return-readmission_en Acesso em: 06 jun. 2021.

COSTA, Vitória; VIEIRA, Luciane. Nacionalismo, xenofobia e União Europeia: barreiras à livre circulação de pessoas e ameaças ao futuro do bloco europeu. Revista da Faculdade de Direito UFPR, Curitiba, v. 64, n. 3, p. 133-160, 2019. Disponível em: https://revistas.ufpr.br/ direito/article/view/65536 Acesso em: 02 jun. 2021.

DEL'OLMO, Florisbal; ROTTA, Guilherme. "BREXIT": da integração regional à política de controle de mobilidade humana. Revista Brasileira de Direito Internacional, Curitiba, v. 2, n. 2, p. 100-117, 2016. Disponível em: www.indexlaw.org/index.php/direitointernacional/article/view/1651/2136 Acesso em: 28 maio 2021.

DIZ, Jamile; JAEGER JÚNIOR, Augusto. Por uma teoria jurídica da integração regional: a interrelação direito interno, direito internacional público e direito da integração. Revista de Direito Internacional, Brasília, v. 12, n. 2, p. 138-158, 2015. Disponível em: www.publicacoesacademicas.uniceub.br/rdi/article/view/3710/pdf\# Acesso em: 02 jun. 2021.

FERREIRA, Susana. Human security and migration in Europe's southern borders. Cham: Palgrave Macmillan, 2019.

FERSTMAN, Carla. Human rights due diligence policies applied to extraterritorial cooperation to prevent "irregular" migration: European Union and United Kingdom Support to Libya. German Law Journal, v. 21, n. 3, p. 459-486, 2020. Disponível em: https://bit. ly/3wNeR4u Acesso em: 02 jun. 2021.

GEDDES, Andrew et al. The dynamics of regional migration governance. Northampton: Edgar Elgar Publishing, 2019.

GEDDES, Andrew. The European Pact on Migration and Asylum. Imiscoe Bulletin, editorial, dez. 2020. Disponível em: https://www.imiscoe.org/news-andblog/bulletin/bulletin-3/1162-the-european-pact-onmigration-and-asylum Acesso em: 01 jun. 2021.

GLITZ, Frederico. Brexit, Direito contratual europeu e Mercosul: lições para a integração. Novos Estudos Jurídicos, v. 23, n. 2, p. 549-577, 2018. Disponível em: https:/ / siaiap32.univali.br/seer/index.php/nej/article/viewFile/13409/7618 Acesso em: 02 jun. 2021.

ILHA, Jônatas; REIS, Jorge. O papel do princípio jurídico da solidariedade no direito da União Europeia em casos de crise migratórias: amor em tempo de muros. Caderno de Relações Internacionais, v. 10, n. 19, p. 71-89, 2019. Disponível em: https://faculdadedamas.edu.br/ revistafd/index.php/relacoesinternacionais/article/ view/1174/906 Acesso em: 30 abr. 2021.

INTERNATIONAL ORGANIZATION FOR MIGRATION. Glossary on migration. Genebra: IOM, 2019.

KRIESI, Hanspeter et al. Debordering and re-bordering in the refugee crisis: a case of 'defensive integration'. Journal of European Public Policy, v. 28, n. 3, p. 331-349, 2021. Disponível $\square$ em: $\square$ www.tandfonline.com/doi/fu 11/10.1080/13501763.2021.1882540 Acesso em: 06 jun. 2021.

LANCEIRO, Rui. Dano e Alimanovic: a recente evolução da jurisprudência do TJUE sobre a cidadania da UE e acesso transfronteiriço aos benefícios sociais. UNIO - EU Law Journal, v. 3, n. 1, p. 65-80, 2017. Disponível em: https://revistas.uminho.pt/index.php/ 
unio/article/download/320/327/636 Acesso em: 02 jul. 2021.

LAUWERS, Nathan; ORBIE, Jan; DELPUT'TE, Sarah. The politicization of the migration-development nexus: parliamentary discourse on the European Union trust fund on migration. Journal of Common Market Studies, v. 59, n. 1, p. 72-90, 2021. Disponível em: https:// onlinelibrary.wiley.com/doi/full/10.1111/jcms.13140. Acesso em 02 jun. 2021.

LAVENEX, Sandra. Migration. In: BORZEL, Tanja; DRAUDE, Anke; RISSE, Thomas. (eds.). The Oxford Handbook of Governance and Limited Statehood. Oxford: Oxford University Press, 2018. p. 520-543.

MOURA, Aline. Caratteri ed effetti della cittadinanza tra diritto internazionale e fenomeni di integrazione regionale: Unione Europea e Mercosul. Tese (Doutorado em Direito) UNIMI, Milão. 2014. Disponível em: https://air.unimi. it/retrieve/handle/2434/231101/300764/phd_unimi_ R09209pdf. Acesso em: 14 abr. 2021.

OELGEMOLLER, Christina; ALLINSON, Kathryn. The Responsible Migrant, Reading the Global Compact on Migration. Law and Critique, v. 31, p. 183-207, 2020. Disponível em: https://link.springer.com/article/10.1007/s10978-020-09265-9 Acesso em: 28 maio 2021.

OSÓRIO, Luiz. O direito da União Europeia e a deterioração democrática e social. Revista Eletrônica do Curso de Direito da UFSM, Santa Maria, v. 13, n. 1, p. 295-318, 2018. Disponível em: https://periodicos.ufsm.br/revistadireito/article/view/29158/pdf Acesso em: 30 maio 2021.

PARLAMENTO EUROPEU. Livre circulação de pessoas. 2021. Disponível em: https://www.europarl.europa.eu/ factsheets/pt/sheet/147/livre-circulacao-de-pessoas Acesso em: 30 maio 2021.

PARLAMENTO EUROPEU. Politica de imigração. 2021. Disponível em: www.europarl.europa.eu/factsheets/ pt/sheet/152/politica-de-imigracao Acesso em: 29 abr. 2021.

PICHON, Eric. The external dimension of the new pact on migration and asylum: a focus on prevention and readmission. European Parliament Think Tank, 2021. Disponível $\square$ em: $\square$ www.europarl.europa. eu/RegData/etudes/BRIE/2021/690535/EPRS_ BRI(2021)690535_EN.pdf Acesso em: 02 jun. 2021.
PORTELA, Paulo. Direito internacional público e privado: incluindo noções de direitos humanos e de direito comunitário. Salvador: Juspodium, 2016.

PORTO, Manuel. O novo pacto sobre migração e asilo: as responsabilidades da Europa. Polis, n. 2, v. 2, p. 97-106, 2020. Disponível em: http://revistas.lis.ulusiada.pt/index.php/polis/article/view/2875/pdf Acesso em: 02 jun. 2021.

SCHIMMELFENNIG, Frank. Rebordering Europe: external boundaries and integration in the European Union. Journal of European Public Policy, v. 28, n. 3, p. 311-330, 2021. Disponível em: www.tandfonline.com/ doi/full/10.1080/13501763.2021.1881589 Acesso em: 28 maio 2021.

SILVA, Wanise; AMARAL, Nemo. A imigração na Europa: a ação política da União Europeia para as migrações extracomunitárias. Sequência, Florianópolis, n. 66, p. 235-259, 2013. Disponível em: https://www.scielo.br/pdf/seq/n66/10.pdf Acesso em: 29 abr. 2021.

SOBRINHO, Liton; SIRIANNI, Guido; PIFFER, Carla. Migrações transnacionais e multiculturalismo: um desafio para a União Europeia. Novos Estudos Jurídicos, v. 19, n. 4, p. 1.159-1.184, 2014. Disponível em: https:// siaiap32.univali.br/seer/index.php/nej/article/view/6702/0 Acesso em: 02 jun. 2021.

STEFAN, Marco; CORTINOVIS, Roberto. Setting the right priorities: is the New Pact on Migration and Asylum addressing the issue of pushbacks at EU external borders? In: CARRERA, Sergio; GEDDES, Andrew (eds.). The EU Pact on Migration and Asylum in light of the United Nations Global Compact on Refugees. Florença: EUI, 2021. p. 180-194.

UNIÃO EUROPEIA. Tribunal de Justiça da União Europeia. Acórdão nos processos apensos C-715/17, C-718/17 e C-719/17. Acórdão de 2 abril 2020. Disponível em: https://bit.ly/3hb2b2L Acesso em: 02 jul. 2021.

UNIÃO EUROPEIA. Tribunal de Justiça da União Europeia. Caso Baumbast(C-413-99). Acórdão de 12 setembro 2002. Disponível em: https://eur-lex.europa.eu/legalcontent/PT/TXT/PDF/?uri=CELEX:61999CJ0413 Acesso em: 02 jul. 2021.

UNIÃO EUROPEIA. Tribunal de Justiça da União Europeia. Caso Celaj (C-290/14). Acórdão de 1 outubro 2015. Disponível em: curia.europa.eu/juris/document/ document.jsf?text $=\&$ docid $=168941$ \&pageIndex $=0 \&$ 
doclang $=$ pt\&mode $=1$ st $\&$ dir $=\& o c c=$ first $\&$ part $=1 \& \mathrm{c}$ id=758346 Acesso em: 30 jun. 2021.

UNIÃO EUROPEIA. Tribunal de Justiça da União Europeia. Caso El Dridi (C-61/11). Acórdão de 28 abril 2011. Disponível em: curia.europa.eu/juris/document/ document.jsf?text $=\&$ docid $=82038 \&$ pageIndex $=0 \&$ doclang $=$ pt\&mode $=1$ st $\&$ dir $=\& o c c=$ first\&part $=1 \& \mathrm{c}$ id=767654 Acesso em: 30 jun. 2021.

UNIÃO EUROPEIA. Tribunal de Justiça da União Europeia. Caso Grželcayyle (C-184/99). Acórdão de 20 setembro 2001. Disponível em: https://bit.ly/3dBmPGP Acesso em: 30 jun. 2021.

VALENTE, Isabel; GUIA, Maria. As políticas europeias de imigração: breve abordagem ao caso português. Anos 90, Porto Alegre, v. 23, n. 43, p. 39-65, 2016. Disponível em: https://seer.ufrgs.br/index.php/anos90/ article/view/62515 Acesso em: 30 maio 2021.

VELOSO, Paulo. Da União à fortaleza ou como a relação de dependência entre migração e integração podem fazer desaparecer a ideia de União Europeia. Revista da Faculdade de Direito da UFMG, Belo Horizonte, n. 75, p. 467-485, 2019. Disponível em: https://revista. direito.ufmg.br/index.php/revista/article/view/2031 Acesso em: 02 jun. 2021.

VIEIRA, Luciane; COSTA, Vitória. A resposta comum da UE frente à pandemia de COVID-19 e os compromissos com a proteção internacional dos direitos humanos de imigrantes e refugiados. In: BAENINGER, Rosana; VEDOVATO, Luís; NANDY Shailen (coord.). Migrações internacionais e a pandemia de Covid-19. Campinas: Nepo/Unicamp, 2020. p. 232-254.

VILLAMAR, Maria. Regionalismos e migrações internacionais na América do Sul: contexto e perspectivas futuras sobre as experiências na Comunidade Andina, no Mercosul e na Unasul. Espaço Aberto, Rio de Janeiro, v. 8, n. 2, p. 131-148, 2018. Disponível em: https:// revistas.ufrj.br/index.php/EspacoAberto/article/ view/20197 Acesso em: 02 jun. 2021.

WENDEN, Catherine Wihtol de. As novas migrações. Dossiê sobre Migrações e Direitos Humanos. Revista Sur, São Paulo, v. 13, n. 23, p. 17-28, 2016. Disponível em: https://sur.conectas.org/wp-content/ uploads/2016/09/1-sur-23-portugues-catherinewihtol-de-wenden.pdf Acesso em: 02 jun. 2021. 
Para publicar na Revista de Direito Internacional, acesse o endereço eletrônico www.rdi.uniceub.br ou www.brazilianjournal.org.

Observe as normas de publicação, para facilitar e agilizar o trabalho de edição. 